\title{
Antimutagenic Effect of the Ellagic Acid and Curcumin Combinations
}

\author{
Zoubková $\mathrm{H}^{*}$, Šmerák $\mathbf{P}$ and Polívková Z \\ Institute of General Biology and Genetics of the 3rd Faculty of Medicine, Charles University, Prague, Czech Republic
}

\begin{abstract}
Introduction: There is an evidence to support the health benefits of diets rich in fruits, vegetables, legumes, whole grains and nuts. Plant-based foods are complex mixtures of bioactive phytochemicals. The potential health effects of individual phytochemicals, their combinations or combinations of phytochemicals and others drugs is studied in detail. Ellagic acid belongs to the group of bioactive polyphenols in fruit: strawberries, raspberries, grapes, black currant and walnuts. Curcumin is a natural compound extracted from the root of Curcuma longa plant.
\end{abstract}

Methods: We perform in vitro Ames test and in vivo micronucleus test toward three mutagens/carcinogens, aflatoxin B1 and 2-amino-3-methylimidazo(4,5-f)quinoline and $\mathrm{N}$-nitroso-N-methylurea to prove an antimutagenic effect of ellagic acid, curcumin and their combinations.

Results: We verified the dose dependent antimutagenic effect of ellagic acid, curcumin and their combinations in both tests. The significantly increased effect of some combinations on the mutagenicity of indirect mutagens in the Ames test and on the direct mutagenicity of MNU in the micronucleus test, as compared with effect of ellagic acid or curcumin used separately, was also ascertained.

Keywords: Phytochemical; Ames; Micronucleus; Carcinogenesis

Abbreviations: DNA: Deoxyribonucleic acid; NF- $\kappa B$ : Nuclear Factor kappa-light-chain-enhancer of activated B cells; VEGF: Vascular Endothelial Growth Factor; PDGF: Platelet-Derived Growth Factor; EA: Ellagic Acid; CRC: Curcumin; TNF: Tumor Necrosis Factor; AP1: Activator Protein 1; IQ: 2-amino-3-methylimidazo(4,5-f)quinolone; $\mathrm{AFB}_{1}$ : Afllatoxin $\mathrm{B}_{1}$; MNU: N-nitroso-N-methylurea; DMSO: Dimethyl Sulfoxide; b.w: Body Weight

Introduction: Exogenousfactors, such as radiation and xenobiotics, can play an important role in carcinogenesis due to their mutagenic/ promoting/co-carcinogenic effects [1]. They induce damage either directly by interacting with the macromolecules or indirectly by the creation of free radicals [2]. If oxidative stress is prolonged, reactive oxygen and nitrogen species are produced and carry out the process of damage. They exacerbate the oxidation of intracellular proteins, lipids, and nucleic acids [3-5]. DNA damage, if left unrepaired, can lead to base mutation, DNA cross-links, single and double-strand breaks, chromosomal breakage and rearrangement [6], genomic instability, neoplastic transformation and, ultimately, carcinogenesis [7]. The covalent interaction of carcinogen-induced reactive species with DNA may result in genotoxic damage during the initiation stage of chemical carcinogenesis [8-9].

This oxidative damage may be prevented or limited by dietary antioxidants (phytochemicals) found in fruits and vegetables [10]. A large number of phytochemicals possess antioxidant and freeradical scavenging properties and are known to modulate important cellular signaling pathways associated with carcinogenesis [7-8]. The epidemiologic studies evaluating associations between intake of a variety of plant-based foods indicate a protective effect, both on cardiovascular diseases and certain cancers. There is appreciable epidemiologic evidence that demonstrates a protective role in diets high in fruits and vegetable, legumes, whole grains and fish on different cancers and cardiovascular diseases [11].
Ellagic acid (EA) belongs to the group of bioactive polyphenols in fruit (strawberries, raspberries, grapes, black currant, walnuts). EA is found in plants in the form of hydrosable tannins called ellagitannins as the structural components of cell wall and cell membrane. EA demonstrates antimutagenic, antioxidant, anti-inflammatory and anticancer activity [12]. Anticancer activity is manifested by blocking initiation of carcinogenesis, suppressing progression and proliferation of tumors $[13,14]$. EA decreases the metabolic activation of carcinogenic substances by inhibition of cytochrome $\mathrm{P} 450$ and by induction of phase II enzymes of metabolic transformation [15]. EA also interferes with multiple cell signaling pathways, including the decrease of NF- $\kappa B$, cyclooxygenase 2, cyclin D1, growth factors VEGF and PDGF and the increase of p21/WAF1 and p53 [14,16,17]. The antiproliferative and proapoptotic activities of EA are proved in cancer cell lines [18].

Curcumin (diferuloymethan) (CRC) is a natural compound extracted from the root of Curcuma longa plant. CRC is an anticancer, antioxidant, antiinflammatory and antiangiogenic agent, capable of inducing apoptosis of cancer cells [19-24]. The protective effect is detected in many in vitro and in vivo studies $[22,25,26]$. Prevalent evidence suggests that it may be useful for the chemoprevention of colon cancer in humans [27]. Preclinical studies of healthy individuals and patients with premalignant conditions or tumors are reviewed by Thomasset 2006 [28] and Von Löw 2007 [29]. The studies of molecular

*Corresponding author: RNDr. Hana Zoubková, PhD, 3rd Faculty of Medicine Charles University, Prague, Institute of General Biology and Genetics, Ruská 87 10000 Praha 10, Czech republic, Tel: + 420267102 492; Fax: + 420267102 464; E-mail: hana.demova@If3.cuni.cz

Received May 11, 2015; Accepted May 27, 2015; Published June 01, 2015

Citation: Zoubková H, Šmerák P, Polívková Z (2015) Antimutagenic Effect of the Ellagic Acid and Curcumin Combinations. J Environ Anal Toxicol 5: 296. doi:10.4172/2161-0525.1000296

Copyright: ( 2015 Zoubková H. This is an open-access article distributed under the terms of the Creative Commons Attribution License, which permits unrestricted use, distribution, and reproduction in any medium, provided the original author and source are credited. 
targets of curcumin reveal that curcumin modulates the expression of many transcription factors such as TNF- $\alpha$, AP- 1 and NF- $\mathrm{KB}$, cell cycle proteins, signal transducting kinases [14,21,30-32]. CRC enhances the expression of cell cycle inhibitors p21 and p27 as well as tumor suppressor protein $\mathrm{p} 53$, but suppress expression of the $\mathrm{Rb}$ protein [33]. CRC also exerts the immunomodulatory effect $[26,34]$.

We have already published the antimutagenic activity of ellagic acid and curcumin as single agents in Ames test, micronucleus test and comet assay $[26,35]$. To prove the presumption about synergism or antagonism of antimutagenic activity of ellagic acid and curcumin, we have studied the activity of their combinations in the Ames test and the micronucleus test and we compared it with the activity of single agents. We used two indirect mutagens/carcinogens aflatoxin $\mathrm{B}_{1}$ and 2-amino3-methylimidazo(4,5-f)quinoline and the direct mutagen/carcinogen $\mathrm{N}$-nitroso-N-methylurea.

\section{Material and Methods}

\section{Ames test}

The antimutagenic activity of ellagic acid, curcumin and their combinations in vitro was detected using the Ames test with Salmonella typhimurium TA98 and TA100 strains [36-39]. Ellagic acid (SigmaAldrich) and curcumin (Sigma-Aldrich) were used at the following concentrations: $0.3 \mu \mathrm{g}, 3 \mu \mathrm{g}, 30 \mu \mathrm{g}$, and $300 \mu \mathrm{g} /$ plate individually and in combinations. Mutagenic substances were used at the following concentrations: $\mathrm{AFB}_{1}$ (Alexis Biochemicals, San Diego, CA, USA) in 10 $\mu \mathrm{g}$ and $1 \mu \mathrm{g}$ per plate in both bacterial strains, IQ (ICN Biomedicals, Eschwege, Germany) in $0.1 \mu \mathrm{g}$ and $0.01 \mu \mathrm{g}$ per plate in the strain TA98, IQ in $10 \mu \mathrm{g}$ and $1 \mu \mathrm{g}$ per plate in the strain TA100. Direct mutagen MNU (Sigma-Aldrich, St. Louis, MO, USA) was used at concentrations of 100 $\mu \mathrm{g}$ and $10 \mu \mathrm{g}$ per plate only in the strain TA100, as these concentrations had no effect in the strain TA98 [26,35]. Each concentration of mutagen was combined with four different concentrations $(0.3 \mu \mathrm{g}, 3 \mu \mathrm{g}, 30 \mu \mathrm{g}$, and $300 \mu \mathrm{g} / \mathrm{plate}$ ) of phytochemical substances individually and also in the following mixtures: $0.3 \mu \mathrm{g}$ of EA $+0.3 \mu \mathrm{g}$ of CRC, $3 \mu \mathrm{g}$ of EA+3 $\mu \mathrm{g}$ of CRC, $30 \mu \mathrm{g}$ of EA+30 $\mu \mathrm{g}$ of CRC and $300 \mu \mathrm{g}$ of EA+300 $\mu \mathrm{g}$ of CRC per plate. All chemicals were diluted in dimethyl sulfoxide (Sigma-Aldrich Co, Lousiana, USA). The S9 fraction of the liver homogenate from the laboratory rats induced by a mixture of polychlorinated biphenyls (Delor) was used for metabolic activation of indirect mutagens [38]. Percentage of inhibition of mutagenicity was calculated by the formula:

No. of revertants of mutagen-No. of revertants of mixture of mutagen and antimutagen(s) $\times 100$

\section{Micronucleus test}

The experiment in vivo, bone marrow micronucleus test, was carried out on male Balb/C mice each weighting 20-24 g (VELAZ s.r.o., Unětice, Czech Republic). The animals were housed under standard conditions and divided into groups of 10 mice for treatment. EA and CRC were tested individually and in combinations. They were applied to mice by gavage three days sequentially, ellagic acid at the doses of 1 and $2 \mathrm{~g} / \mathrm{kg}$ b.w. and curcumin at the doses of 0.25 and $0.5 \mathrm{~g} / \mathrm{kg}$ b.w. The combinations of them were used in concentrations: $1 \mathrm{~g}$ of EA $/ \mathrm{kg}+0.25$ $\mathrm{g}$ of CRC $/ \mathrm{kg}$ and $2 \mathrm{~g}$ of EA $/ \mathrm{kg}+0.5 \mathrm{~g}$ of CRC $/ \mathrm{kg}$ b.w. Mutagens $\left(\mathrm{AFB}_{1}\right.$, $\mathrm{IQ}$, and MNU) were applied individually and also in the mixtures with phytochemicals. $\mathrm{AFB}_{1}$ was used in the concentration of $1 \mathrm{mg} / \mathrm{kg}$ b.w., IQ was used in the concentration of $20 \mathrm{mg} / \mathrm{kg}$ b.w. and MNU in the concentration of $50 \mathrm{mg} / \mathrm{kg}$ b.w. Mutagens were applied in the single dose on the third day. All substances (diluted in DMSO) were applied in volumes of $100 \mu \mathrm{l} / 10 \mathrm{~g}$ b.w. The control group of mice received $7 \%$ solution of DMSO orally. The micronucleus test on mouse bone marrow was carried out according to Schmid, 1975 [40]. A total number of 1000 polychromatophilic erythrocytes were scored per animal for an evaluation of frequencies of micronuclei.

All groups of samples were tested in two separate experiments and each sample was tested in three plates in the Ames test. In the micronucleus test, all samples were tested in three separate experiments. For statistical analysis we used Student's t-test.

\section{Results}

\section{Results of Ames test}

The results of the Ames test are presented in Tables 1-4. They are expressed as a number of revertants and also as a percentage of inhibition of mutagenic activity. The samples of EA, CRC and their combinations were tested separately without mutagen (Table 1 ), and in combination with mutagen $\mathrm{AFB}_{1}$ (Table 2), with mutagen IQ (Table 3) and with mutagen MNU (Table 4). An activity of mixtures of EA and CRC were compared to the results of phytochemicals used separately all in combination with mutagens (Tables 2-4). Neither ellagic acid and curcumin, nor their combinations revealed any mutagenicity in both bacterial strains TA98 and TA100 (Table 1). Significant dose dependent antimutagenic activity was detected at two highest concentrations (30 and $300 \mu \mathrm{g} /$ plate) of EA, CRC and their combinations on mutagenicity of both concentrations of $\mathrm{AFB}_{1}$ (10 and $1 \mu \mathrm{g} /$ plate) (Table 2$)$. The only exception of significance was in the decrease of mutagenicity of the combinations of $30 \mu \mathrm{g}$ of EA/plate mixed with $10 \mu \mathrm{g}$ of $\mathrm{AFB}_{1}$ in both bacterial strains and $30 \mu \mathrm{g}$ of EA mixed with $1 \mu \mathrm{g}$ of $\mathrm{AFB}_{1}$ in the strain TA 100 (Table 2). In both strains, the antimutagenic activity of two combinations $(3 \mu \mathrm{g}$ of EA+3 $\mu \mathrm{g}$ of CRC and $30 \mu \mathrm{g}$ of EA+ $30 \mu \mathrm{g}$ of CRC mixed with $1 \mu \mathrm{g}$ of $\mathrm{AFB}_{1}$ ) was significantly higher than the activity of the same concentrations of EA or CRC used separately.

The dose dependent inhibition effect of phytochemicals and their combinations were detected on mutagenicity of both concentrations of IQ $(0.1$ and $0.01 \mu \mathrm{g} /$ plate in the strain TA98 and 10 and $1 \mu \mathrm{g} /$ plate in the strain TA100) (Table 3). There was significant difference between combinations with concentrations of $30 \mu \mathrm{g}$ of EA+30 $\mu \mathrm{g}$ of CRC combined with $0.1 \mu \mathrm{g}$ or $0.01 \mu \mathrm{g}$ of IQ in the strain TA98 and in the concentrations of $3 \mu \mathrm{g}$ of EA+3 $\mu \mathrm{g}$ of CRC and $30 \mu \mathrm{g}$ of EA+30 $\mu \mathrm{g}$ of CRC both combined with $1 \mu \mathrm{g}$ of IQ in the strain TA100 than EA or CRC of the same concentrations used separately (Table 3).

The activity of phytochemicals against the direct mutagen MNU, used at concentration of $100 \mu \mathrm{g} /$ plate was significant only in the combinations of phytochemicals with higher concentrations (30 $\mu \mathrm{g}$ of EA+30 $\mu \mathrm{g}$ of CRC, $300 \mu \mathrm{g}$ of EA+300 $\mu \mathrm{g}$ of CRC) (Table 4). The differences between the activity of combinations and separate phytochemicals were not significant. The antimutagenic activity against lower concentration of MNU ( $10 \mu \mathrm{g} /$ plate) was more obvious, but the effect of phytochemicals combinations similarly did not differ from the effect of EA or CRC used separately (Table 4).

\section{Results of micronucleus test}

All three mutagens revealed significant mutagenic activity in the micronucleus test. The number of micronuclei in animals, which received phytochemicals and their combinations without mutagen, did not differ from those of the control group (Table 5). EA, CRC and their combinations significantly reduced the number of micronuclei, which was high by the mutagenic activity of $\mathrm{AFB}_{1}$, IQ and MNU. The decrease of micronuclei numbers was dose dependent (Figures 1-3). The activity 
Citation: Zoubková H, Šmerák P, Polívková Z (2015) Antimutagenic Effect of the Ellagic Acid and Curcumin Combinations. J Environ Anal Toxicol 5: 296. doi:10.4172/2161-0525.1000296

Page 3 of 8

\begin{tabular}{|c|c|c|c|c|}
\hline \multirow{2}{*}{$\begin{array}{c}\text { EA+CRC } \\
\text { dose }(\boldsymbol{\mu g} / \mathbf{p l a t e})\end{array}$} & \multicolumn{2}{|c|}{ S. typhimurium TA98+S9 } & \multicolumn{2}{|c|}{ S. typhimurium TA100+S9 } \\
\cline { 2 - 5 } & No of revertants & $\mathbf{\pm} \mathbf{S D}$ & No of revertants & $\mathbf{\pm} \mathbf{S D}$ \\
\hline 0.3EA & 20 & 5 & 79 & 3 \\
\hline 3EA & 24 & 5 & 78 & 6 \\
\hline 30EA & 20 & 3 & 69 & 10 \\
\hline 300EA & 17 & 2 & 67 & 7 \\
\hline 0.3CRC & 18 & 5 & 81 & 9 \\
\hline 3CRC & 22 & 4 & 71 & 6 \\
\hline 30CRC & 19 & 5 & 70 & 7 \\
\hline 300CRC & 17 & 5 & 68 & 5 \\
\hline 0.3EA+0.3CRC & 18 & 2 & 74 & 8 \\
\hline 3EA+3CRC & 20 & 6 & 73 & 9 \\
\hline 30EA+30CRC & 16 & 4 & 70 & 8 \\
\hline 300EA+300CRC & 20 & 7 & 68 & 3 \\
\hline control - DMSO & 22 & 4 & 79 & 9 \\
\hline
\end{tabular}

of the combinations of EA and CRC on the mutagenicity of indirect mutagens $\mathrm{AFB}_{1}$ and IQ did not differ from the activity of phytochemicals used separately (Figures 1 and 2). Only the mutagenicity of $50 \mathrm{mg} / \mathrm{kg}$ of MNU was significantly more reduced by the combination of EA and CRC at concentrations of $2 \mathrm{~g} / \mathrm{kg}$ of EA $+0.5 \mathrm{mg} / \mathrm{kg}$ of CRC in three daily doses in comparison with the same doses of individual phytochemicals (Figure 3).

\section{Discussion}

Antimutagenesis, a prevention of genotoxic damage is a part of chemoprevention and could be considered as a major mechanism to inhibit carcinogenesis in the initiation stage [9]. Chemoprevention, as a defense anti-cancer mechanism provided by phytochemicals, was defined in 1966 by Wattenberg [41]. In our department, we studied the antimutagenic and immuno-modulatory effects of individual phytochemicals of natural origin both in vitro and in vivo conditions. We confirmed that the phytochemicals in the pure forms

Table 1: Ellagic acid, curcumin and their combinations in Ames test.

\begin{tabular}{|c|c|c|c|c|c|c|}
\hline \multirow[b]{2}{*}{$\begin{array}{c}\mathrm{AFB}_{1}+\text { antimutagen(s) } \\
\text { dose ( } \mu \text { g/plate) }\end{array}$} & \multicolumn{3}{|c|}{ S. typhimurium TA98+S9 } & \multicolumn{3}{|c|}{ S. typhimurium TA100+S9 } \\
\hline & No of revertants & $\pm S D$ & $\begin{array}{c}\% \text { of } \\
\text { inhibition }\end{array}$ & No of revertants & $\pm S D$ & $\begin{array}{c}\% \text { of } \\
\text { inhibition }\end{array}$ \\
\hline $10+0$ & 471 & 94 & & 762 & 90 & \\
\hline $1+0$ & 559 & 100 & & 703 & 72 & \\
\hline $10+0.3 E A$ & 446 & 67 & -5 & 729 & 114 & -4 \\
\hline $10+3 E A$ & 467 & 81 & -1 & 701 & 129 & -8 \\
\hline $10+30 \mathrm{EA}$ & 406 & 119 & -14 & 685 & 131 & -10 \\
\hline $10+300 \mathrm{EA}$ & $127^{* *}$ & 42 & -73 & $501^{* *}$ & 134 & -34 \\
\hline $10+0.3 \mathrm{CRC}$ & 446 & 117 & -5 & 666 & 141 & -13 \\
\hline $10+3 \mathrm{CRC}$ & 456 & 99 & -3 & 641 & 138 & -16 \\
\hline $10+30 \mathrm{CRC}$ & $67^{* *}$ & 25 & -86 & $522^{* *}$ & 212 & -32 \\
\hline $10+300 \mathrm{CRC}$ & $9^{* *}$ & 5 & -98 & $226^{* *}$ & 108 & -70 \\
\hline $10+0.3 E A+0.3 C R C$ & 434 & 41 & -8 & $605^{*}$ & 168 & -21 \\
\hline $10+3 E A+3 C R C$ & 474 & 38 & +1 & $601^{*}$ & 174 & -21 \\
\hline $10+30 E A+30 C R C$ & $73^{* *}$ & 30 & -85 & $480^{* *}$ & 193 & -37 \\
\hline $10+300 E A+300 C R C$ & $12^{* *}$ & 7 & -98 & $146^{* *}$ & 67 & -81 \\
\hline $1+0.3 \mathrm{EA}$ & 548 & 56 & -2 & 703 & 100 & 0 \\
\hline $1+3 \mathrm{EA}$ & 573 & 26 & +3 & 681 & 88 & -3 \\
\hline $1+30 \mathrm{EA}$ & $449^{*}$ & 88 & -20 & 634 & 158 & -10 \\
\hline $1+300 \mathrm{EA}$ & $54^{* *}$ & 18 & -90 & $244^{* *}$ & 109 & -65 \\
\hline $1+0.3 \mathrm{CRC}$ & 591 & 39 & +6 & 644 & 108 & -8 \\
\hline $1+3 \mathrm{CRC}$ & 575 & 22 & +3 & 663 & 80 & -6 \\
\hline $1+30 \mathrm{CRC}$ & $103^{* *}$ & 31 & -82 & $532^{* *}$ & 129 & -24 \\
\hline $1+300 \mathrm{CRC}$ & $36^{*+}$ & 22 & -94 & $147^{* *}$ & 41 & -79 \\
\hline
\end{tabular}


Citation: Zoubková H, Šmerák P, Polívková Z (2015) Antimutagenic Effect of the Ellagic Acid and Curcumin Combinations. J Environ Anal Toxicol 5: 296. doi:10.4172/2161-0525.1000296

Page 4 of 8

\begin{tabular}{|c|c|c|c|c|c|c|}
\hline $1+0.3 E A+0.3 C R C$ & 511 & 81 & -9 & 581 & 166 & -17 \\
\hline $1+3 E A+3 C R C$ & $481^{* \star V}$ & 73 & -14 & $516^{* * V}$ & 104 & -27 \\
\hline $1+30 \mathrm{EA}+30 \mathrm{CRC}$ & $57^{* \top \mathrm{V}}$ & 8 & -90 & $193^{*+\nabla}$ & 89 & -73 \\
\hline $1+300 E A+300 C R C$ & $23^{* *}$ & 13 & -96 & $107^{* *}$ & 33 & -85 \\
\hline control-DMSO & 22 & 6 & & 101 & 14 & \\
\hline
\end{tabular}

SD: Standard Deviation

*Statistically significant difference between the sample with mutagen and antimutagen(s) and the sample with specific mutagen (1) $p \leq 0.05$

${ }^{*}$ Statistically significant difference between the sample with mutagen and antimutagen(s) and the sample with specific mutagen (1) $p \leq 0.01$

$\checkmark$ Statistically significant difference between the sample with combination of antimutagens and samples with specific antimutagen

Table 2: Effect of EA, CRC and their combinations on mutagenicity of $\mathrm{AFB}_{1}$ in Ames test.

\begin{tabular}{|c|c|c|c|c|c|c|c|}
\hline \multicolumn{4}{|c|}{ S. typhimurium TA98+S9 } & \multicolumn{4}{|c|}{ S. typhimurium TA100+S9 } \\
\hline $\begin{array}{l}\text { IQ+antimutagen(s) } \\
\text { dose ( } \mu \text { g/plate) }\end{array}$ & No of revertants & $\pm S D$ & $\begin{array}{c}\% \text { of } \\
\text { inhibition }\end{array}$ & $\begin{array}{l}\text { IQ+antimutagen(s) } \\
\text { dose }(\mu \mathrm{g} / \text { plate })\end{array}$ & No of revertans & $\pm S D$ & $\begin{array}{c}\% \text { of } \\
\text { inhibition }\end{array}$ \\
\hline $0.1+0$ & 1365 & 145 & & $10+0$ & 586 & 104 & \\
\hline $0.01+0$ & 497 & 166 & & $1+0$ & 711 & 79 & \\
\hline $0.1+0.3 \mathrm{EA}$ & 1211 & 194 & -11 & $10+0.3 E A$ & 577 & 71 & -2 \\
\hline $0.1+3 E A$ & $1141^{* *}$ & 157 & -16 & $10+3 E A$ & 579 & 97 & -1 \\
\hline $0.1+30 E A$ & $244^{* *}$ & 97 & -82 & $10+30 \mathrm{EA}$ & $161^{* *}$ & 25 & -73 \\
\hline $0.1+300 E A$ & $32^{* *}$ & 8 & -98 & $10+300 \mathrm{EA}$ & $98^{* *}$ & 17 & -83 \\
\hline $0.1+0.3 \mathrm{CRC}$ & 1267 & 197 & -7 & $10+0.3 \mathrm{CRC}$ & 588 & 100 & 0 \\
\hline $0.1+3 \mathrm{CRC}$ & $1060^{* *}$ & 189 & -22 & $10+3 C R C$ & 571 & 128 & -3 \\
\hline $0.1+30 \mathrm{CRC}$ & $528^{* *}$ & 140 & -61 & $10+30 \mathrm{CRC}$ & $446^{*}$ & 92 & -24 \\
\hline $0.1+300 \mathrm{CRC}$ & $18^{* *}$ & 4 & -99 & $10+300 \mathrm{CRC}$ & $346^{* *}$ & 109 & -41 \\
\hline $0.1+0.3 E A+0.3 C R C$ & $1195^{*}$ & 180 & -13 & $10+0.3 E A+0.3 C R C$ & 595 & 100 & +2 \\
\hline $0.1+3 E A+3 C R C$ & $1032^{* *}$ & 192 & -24 & $10+3 E A+3 C R C$ & $465^{\star}$ & 96 & -21 \\
\hline $0.1+30 E A+30 C R C$ & $53^{* *}$ & 31 & -96 & $10+30 E A+30 C R C$ & $151^{* *}$ & 69 & -74 \\
\hline $0.1+300 \mathrm{EA}+300 \mathrm{CRC}$ & $23^{* *}$ & 5 & -98 & $10+300 \mathrm{EA}+300 \mathrm{CRC}$ & $83^{* *}$ & 12 & -86 \\
\hline $0.01+0.3 \mathrm{EA}$ & 419 & 179 & -16 & $1+0.3 \mathrm{EA}$ & $619^{*}$ & 104 & -13 \\
\hline $0.01+3 E A$ & 416 & 125 & -16 & $1+3 \mathrm{EA}$ & $609^{* *}$ & 45 & -14 \\
\hline $0.01+30 \mathrm{EA}$ & $66^{* *}$ & 36 & -87 & $1+30 \mathrm{EA}$ & $240^{* *}$ & 79 & -66 \\
\hline $0.01+300 \mathrm{EA}$ & $29^{*+}$ & 5 & -94 & $1+300 \mathrm{EA}$ & $96^{*+}$ & 19 & -87 \\
\hline $0.01+0.3 \mathrm{CRC}$ & 480 & 149 & -3 & $1+0.3 \mathrm{CRC}$ & 681 & 114 & -4 \\
\hline $0.01+3 \mathrm{CRC}$ & 424 & 127 & -15 & $1+3 \mathrm{CRC}$ & $604^{* *}$ & 113 & -15 \\
\hline $0.01+30 \mathrm{CRC}$ & $187^{* *}$ & 85 & -62 & $1+30 \mathrm{CRC}$ & $415^{* *}$ & 79 & -42 \\
\hline $0.01+300 \mathrm{CRC}$ & $25^{* *}$ & 8 & -95 & $1+300 \mathrm{CRC}$ & $163^{* *}$ & 45 & -77 \\
\hline $0.01+0.3 E A+0.3 C R C$ & 363 & 175 & -27 & $1+0.3 E A+0.3 C R C$ & $585^{* *}$ & 129 & -18 \\
\hline $0.01+3 E A+3 C R C$ & $337^{\star}$ & 148 & -32 & $1+3 E A+3 C R C$ & $514^{* * \nabla}$ & 69 & -28 \\
\hline $0.01+30 \mathrm{EA}+30 \mathrm{CRC}$ & $32^{* *}$ & 10 & -94 & $1+30 \mathrm{EA}+30 \mathrm{CRC}$ & $120^{* *} \mathbf{V}$ & 22 & -83 \\
\hline $0.01+300 E A+300 C R C$ & $24^{* *}$ & 8 & -95 & $1+300 \mathrm{EA}+300 \mathrm{CRC}$ & $84^{* *}$ & 9 & -88 \\
\hline control-DMSO & 28 & 6 & & control-DMSO & 83 & 6 & \\
\hline
\end{tabular}

SD standard deviation

* Statistically significant difference between the sample with mutagen and antimutagen(s) and the sample with specific mutagen $p \leq 0.05$

**Statistically significant difference between the sample with mutagen and antimutagen(s) and the sample with specific mutagen (1) $p \leq 0.01$

V Statistically significant difference between the sample with combination of antimutagens and samples with specific antimutagens Table 3: Effect of EA, CRC and their combinations on mutagenicity of IQ in Ames test.

and also in the form of juices of natural plants might have an important role in the prevention of carcinogenesis by their antimutagenic effect $[26,35,42-47]$. In adition, it was presented by other research groups that CRC and EA were able to activate or inhibit many cellular molecules of signaling pathways and became involved in the regulation of cancer cell division [14].
Food phytochemicals provided complex interactions in biological systems [48]. The combination of natural phytochemicals in fruits and vegetables, which provided health benefits, might not be replaced by the effect of single phytochemicals [10,49]. Also, combinations of phytochemicals might have result in significant effect at concentrations, in which the single agents were inactive [50]. 
Citation: Zoubková H, Šmerák P, Polívková Z (2015) Antimutagenic Effect of the Ellagic Acid and Curcumin Combinations. J Environ Anal Toxicol 5: 296. doi:10.4172/2161-0525.1000296

Page 5 of 8

\begin{tabular}{|c|c|c|c|}
\hline \multirow[b]{2}{*}{$\begin{array}{c}\text { MNU+antimutagen(s) } \\
\text { dose ( } \mu \mathrm{g} / \mathrm{plate})\end{array}$} & \multicolumn{3}{|c|}{ S. typhimurium TA100 } \\
\hline & No of revertants & $\pm S D$ & $\%$ of inhibition \\
\hline $100+0$ & 1643 & 166 & \\
\hline $10+0$ & 392 & 26 & \\
\hline $100+0.3 E A$ & 1624 & 164 & -1 \\
\hline $100+3 E A$ & 1658 & 145 & +1 \\
\hline $100+30 E A$ & 1567 & 166 & -5 \\
\hline $100+300 \mathrm{EA}$ & 1359 & 223 & -17 \\
\hline $100+0.3 \mathrm{CRC}$ & 1619 & 209 & -2 \\
\hline $100+3 C R C$ & 1536 & 263 & -7 \\
\hline $100+30 \mathrm{CRC}$ & 1490 & 212 & -9 \\
\hline $100+300 \mathrm{CRC}$ & 1243 & 228 & -24 \\
\hline $100+0.3 E A+0.3 C R C$ & 1569 & 205 & -5 \\
\hline $100+3 E A+3 C R C$ & 1481 & 236 & -10 \\
\hline 100+30EA+30CRC & $1288^{*}$ & 240 & -22 \\
\hline $100+300 E A+300 C R C$ & $1015^{\prime \prime}$ & 243 & -38 \\
\hline $10+0.3 \mathrm{EA}$ & 414 & 35 & +6 \\
\hline 10+3EA & 407 & 69 & +4 \\
\hline $10+30 \mathrm{EA}$ & 327 & 126 & -17 \\
\hline $10+300 E A$ & $254^{* *}$ & 32 & -35 \\
\hline $10+0.3 \mathrm{CRC}$ & 385 & 47 & -2 \\
\hline $10+3 \mathrm{CRC}$ & 422 & 90 & +8 \\
\hline $10+30 \mathrm{CRC}$ & $211^{\prime \prime}$ & 21 & -46 \\
\hline $10+300 \mathrm{CRC}$ & $154^{* *}$ & 9 & -61 \\
\hline $10+0.3 \mathrm{EA}+0.3 \mathrm{CRC}$ & 406 & 89 & +4 \\
\hline $10+3 E A+3 C R C$ & 364 & 69 & -7 \\
\hline 10+30EA+30CRC & $187^{* \prime}$ & 29 & -52 \\
\hline $10+300 E A+300 C R C$ & $144 "$ & 16 & -63 \\
\hline control-DMSO & 112 & 9 & \\
\hline
\end{tabular}

SD standard deviation

*Statistically significant difference between the sample with mutagen and antimutagen(s) and the sample with specific mutagen $p \leq 0.05$

**Statistically significant difference between the sample with mutagen and antimutagen(s) and the sample with specific mutagen $p \leq 0.01$

Table 4: Effect of EA, CRC and their combinations on mutagenicity of MNU in Ames test.

\begin{tabular}{|c|c|c|c|}
\hline $\begin{array}{c}\text { Substances } \\
\text { tested }\end{array}$ & Dose & No of micronuclei & SD \\
\hline EA & $3 \times 1 \mathrm{~g} / \mathrm{kg}$ & 0.4 & 0.5 \\
\hline $\mathrm{EA}$ & $3 \times 2 \mathrm{~g} / \mathrm{kg}$ & 0.2 & 0.4 \\
\hline $\mathrm{CRC}$ & $3 \times 0.25 \mathrm{~g} / \mathrm{kg}$ & 0.6 & 0.9 \\
\hline CRC & $3 \times 0.5 \mathrm{~g} / \mathrm{kg}$ & 0.4 & 0.5 \\
\hline EA+CRC & $3 \times(1+0.25) \mathrm{g} / \mathrm{kg}$ & 0.4 & 0.5 \\
\hline EA+CRC & $3 \times(2+0.5) \mathrm{g} / \mathrm{kg}$ & 0.2 & 0.4 \\
\hline control-DMSO & - & 0.2 & 0.4 \\
\hline
\end{tabular}

SD: Standard Deviation

Table 5: Ellagic acid, curcumin and their combinations in micronucleus test.

Interactions of phytochemicals might be antagonistic, additive and/ or synergistic depending on the certain experimental conditions and concentrations $[48,49]$. The additive or synergistic effect of combinations of phytochemicals or phytochemicals and synthetic drugs was previously detected in many research projects under both in vitro and in vivo conditions [51-58]. For instance, Verma et al. (1997) described a synergistic inhibition effect of curcumin and genistein on proliferation of MCF-7 breast cells induced by estrogenic pesticides [51]. Lev-Ari et al. (2005) provided that curcumin synergistically

potentiated the growth inhibition and the pro-apoptotic effect of celecoxib in pancreatic adenocarcinoma cells [52] or colorectal cancer cells [53]. Also ellagic acid and guercetin interacted synergistically with resveratrol in the induction of apoptosis in human leukemia cells [54]. Resveratrol combinations with ellagic acid and other phytochemicals were very potent inhibitors of skin tumorgenesis [55].

In our research the antimutagenic effect of the combinations of phytochemicals and individual phytochemicals of the same high concentrations was detected on mutagenicity of both concentrations of indirect mutagens, $\mathrm{AFB}_{1}$ and $\mathrm{IQ}$, in the Ames test. The increased antimutagenic effect of the combinations was mostly detected in two middle concentrations of phytochemicals ( 3 and $30 \mu$ of EA and CRC) in the comparision to the effect of individual phytochemicals of the same concentration. The increased significant antimutagenic effect of combinations was limited by concentration. Considering these results, we could not confirm the presumption about effective low-concentration combinations of tested phytochemicals [50]. The combination of the highest concentration $(300 \mu \mathrm{g}$ of EA and CRC) did not show an

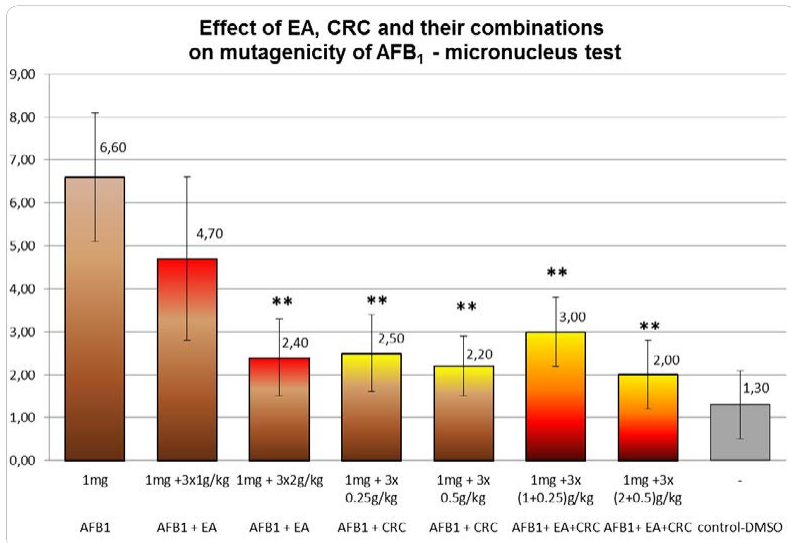

*Statistically significant difference between the sample with mutagen and antimutagen(s) and the sample with specific mutagen $p \leq 0.05$.

**Statistically significant difference between the sample with mutagen and antimutagen(s) and the sample with specific mutagen $p \leq 0.01$.

Figure 1: Effect of $E A, C R C$ and their combinations on mutagenicity of $A_{F} B_{1}$ in micronucleus test.

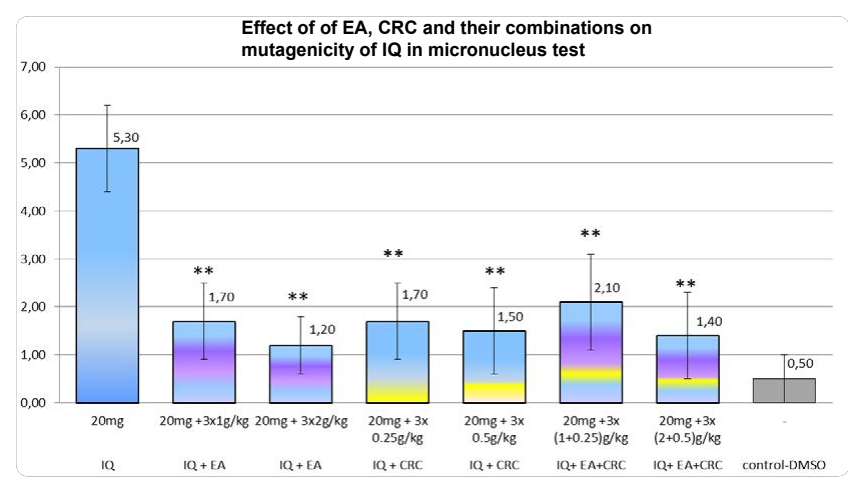

*Statistically significant difference between the sample with mutagen and antimutagen(s) and the sample with specific mutagen $p \leq 0.05$.

**Statistically significant difference between the sample with mutagen and antimutagen(s) and the sample with specific mutagen $p \leq 0.01$.

Figure 2: Effect of EA, CRC and their combinations on mutagenicity of IQ in micronucleus test. 


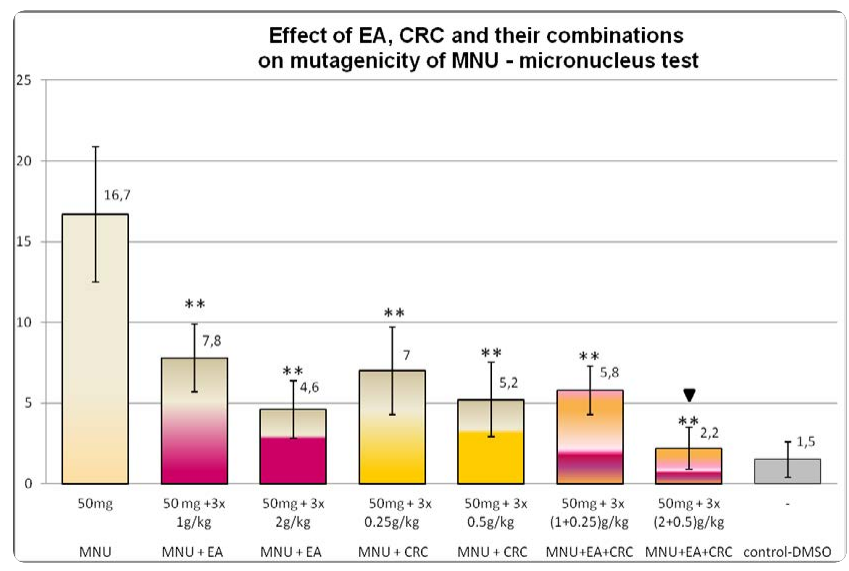

*Statistically significant difference between the sample with mutagen and antimutagen(s) and the sample with specific mutagen (1) $p \leq 0.05$.

**Statistically significant difference between the sample with mutagen and antimutagen(s) and the sample with specific mutagen (1) $p \leq 0.01$.

$\boldsymbol{\nabla}$ Statistically significant difference between the sample with combination of antimutagens and samples with specific antimutagen.

Figure 3: Effect of EA, CRC and their combinations on mutagenicity of MNU in micronucleus test.

increased effect against indirect mutagens in the Ames test. The results support the presumption of the "saturation effect" by Abraham et al. (2012) [1]. The effect of phytochemicals against the direct mutagen MNU was proven mainly in the combinations of phytochemicals of high concentration. If we compared the effect of phytochemicals against the direct and indirect mutagens, the antimutagenic effect was stronger against the indirect mutagens. It might be indicative of importance of a biotransformation process of indirect mutagens in metabolism. The effect of CRC and EA on metabolic activation or detoxication of carcinogens was previously proven. They have an inhibitory effect towards cytochrome P450 enzymes [59-61] and in vivo induce GST enzymes of rat liver [62,63].

In micronucleus test, both phytochemicals and their combinations provided a significant decrease in the number of micronuclei induced by mutagens. The increased significant antimutagenic effect of the combinations of EA and CRC in comparison with the effect of the phytochemicals used individually of the same concentration was detected in the highest concentration $(2 \mathrm{~g}$ of $\mathrm{EA} / \mathrm{kg}+0.5 \mathrm{~g}$ of $\mathrm{CRC} / \mathrm{kg}$ b.w) of phytochemicals against direct mutagen MNU. The interaction of phytochemicals might indicate the potentiation, additivity or synergism, if the compounds act via different mechanisms and/or on different targets [64]. The potentiation of effects of phytochemicals was usually verified, if the effect included many molecular targets [49]. EA and CRC differ slightly in molecular size and solubility, which might affect the bioavailability and distribution in different macromolecules, subcellular organelles, cells, organs and tissues [64]. The other possible mechanism of increasing protective effect of the EA and CRC combination might be the mutual stabilization of their molecules, because phytochemicals tend to increase the therapeutic effect by increasing the bioavailability of the other drug or, by stabilizing the other drug in the system [50]. A possible explanation of the increased antimutagenic effect the EA and CRC combinations might be the combination of the above mentioned mechanisms.

Recent research on protective phytochemicals contributed to understanding their chemical and biological functions and their beneficial effects on human health [65]. There was growing evidence that the combinations of two or more compounds might be more efficacious. Many phytochemicals were reported to act synergistically, which might explain why some food items or diets show cancer preventive effects, which could not be explained based on individual bioactive ingredients [49]. The synergistic effects of dietary phytochemicals should be further explored for additional beneficial and reliable outcomes in the field of cancer prevention [66]. Because of pharmacological safety, some chemoprotective agents of natural origin could be used not only to prevent cancer, but also to treat cancer in combination with chemotherapy. In adition, natural products had the potential to provide the pharmacologist with a source of novel structures, on the basis of which most current cancer drugs were synthesized [50]. Recent studies showed that phytochemicals were also able to reverse the chemoresistance or radioresistance of tumor cells [66,67]. More information about the combined effects of phytochemicals is needed to avoid the possible unfavorable effects of their unbalanced combinations.

\section{Conclusion}

In Ames test (in vitro) and in micronucleus test (in vivo), ellagic acid and curcumin did not show any mutagenic effect to bacteria and mice. We verified the antimutagenic effect of ellagic acid and curcumin against the indirect mutagens IQ and $\mathrm{AFB}_{1}$ and against the direct mutagen $\mathrm{MNU}$ in the Ames test and in the micronucleus test. The antimutagenic effect of ellagic acid and curcumin was dose dependent. An increased antimutagenic effect of the ellagic acid and curcumin combinations was proved in the Ames test against the indirect mutagens $\mathrm{IQ}$ and $\mathrm{AFB}_{1}$ and in the micronucleus test against the direct mutagen $\mathrm{MNU}$ as compared with effect of ellagic acid or curcumin used separately.

\section{Acknowledgements}

The authors thank to Mrs. V. Filipiová, Mrs. M. Benešová, and Mrs. J. Jalovecká for their technical help and assistance. The authors also thank to Mgr Thomas Tyre O'Hearn for effective proofreading of our text in English.

\section{Declaration of Interest Statement}

This project was supported by the Research program of Charles University code UNCE 204015 and research project P27/2012 awarded by Charles University, $3^{\text {rd }}$ Faculty of Medicine in Prague. No other people or organizations have financial, consulting, or personal relationships with our work and our manuscript.

\section{References}

1. Abraham SK, Eckhardt A, Oli RG, Stopper H (2012) Analysis of in vitro chemoprevention of genotoxic damage by phytochemicals, as single agents or as combinations. Mutat Res 744: 117-124.

2. Nambiar D, Rajamani P, Singh RP (2011) Effects of phytochemicals on ionization radiation-mediated carcinogenesis and cancer therapy. Mutat Res 728: 139-157.

3. Kong AN, Mandlekar S, Yu R, Lei W, Fasanmande A (1999) Pharmacodynamics and toxicodynamics of drug action: signaling in cell survival and cell death Pharm Res 16: 790-798

4. Ma DD, Lu HX, Xu LS, Xiao W (2009) Polyphyllin D exerts potent anti-tumour effects on Lewis cancer cells under hypoxic conditions. J Int Med Res 37: 631 640

5. Schetter AJ, Heegaard NH, Harris CC (2010) Inflammation and cancer: interweaving microRNA, free radical, cytokine and p53 pathways. Carcinogenesis 31: 37-49.

6. Ames BN, Shigenaga MK, Gold LS (1993) DNA lesions, inducible DNA repair and cell division: three key factors in mutagenesis and carcinogenesis. Environ Health Perspect 101 Suppl 5: 35-44.

7. Lee KW, Bode AM, Dong Z (2011) Molecular targets of phytochemicals for cancer prevention. Nat Rev Cancer 11: 211-218. 
Citation: Zoubková H, Šmerák P, Polívková Z (2015) Antimutagenic Effect of the Ellagic Acid and Curcumin Combinations. J Environ Anal Toxicol 5: 296. doi:10.4172/2161-0525.1000296

Page 7 of 8

8. Surh YJ (2003) Cancer chemoprevention with dietary phytochemicals. Nature Reviews Cancer 3: 768-780.

9. De Flora S, Izzotti A, D'Agostini F, Balansky RM, Noonan D, et al. (2001) Multiple points of intervention in the prevention of cancer and other mutationrelated diseases. Mutat Res 480-481: 9-22.

10. Liu RH (2004) Potential synergy of phytochemicals in cancer prevention: mechanism of action. J Nutr 134: 3479S-3485S

11. Kris-Etherton PM, Hecker KD, Bonanome A, Coval SM, Binkoski AE, et al. (2002) Bioactive compounds in foods: their role in the prevention of cardiovascular disease and cancer. Am J Med 113 Suppl 9B: 71S-88S.

12. Vattem DA, Shetty K (2005) Biological functionality of ellagic acid: a review. Journal of Food Biochemistry 29: 234-266.

13. Hannum SM (2004) Potential impact of strawberries on human health: a review of the science. Crit Rev Food Sci Nutr 44: 1-17.

14. Aggarwal BB, Shishodia S (2006) Molecular targets of dietary agents for prevention and therapy of cancer. Biochem Pharmacol 71: 1397-1421.

15. Ahn D, Putt D, Kresty L, Stoner GD, Fromm D, et al. (1996) The effects of dietary ellagic acid on rat hepatic and esophageal mucosal cytochromes P450 and phase II enzymes. Carcinogenesis 17: 821-828.

16. Li TM, Chen GW, Su CC, Lin JG, Yeh CC, et al. (2005) Ellagic acid induced p53/ p21 expression, G1 arrest and apoptosis in human bladder cancer T24 cells. Anticancer Res 25: 971-979.

17. Labrecque L, Lamy S, Chapus A, Mihoubi S, Durocher Y, et al. (2005) Combined inhibition of PDGF and VEGF receptors by ellagic acid, a dietaryderived phenolic compound. Carcinogenesis 26: 821-826.

18. Seeram NP, Adams LS, Henning SM, Niu Y, Zhang Y, et al. (2005) In vitro antiproliferative, apoptotic and antioxidant activities of punicalagin, ellagic acid and a total pomegranate tannin extract are enhanced in combination with other polyphenols as found in pomegranate juice. J Nutr Biochem 16: 360-367.

19. Conney $\mathrm{AH}$ (2003) Enzyme induction and dietary chemicals as approaches to cancer chemoprevention: the Seventh DeWitt S. Goodman Lecture. Cancer Res 63: 7005-7031.

20. Campbell FC, Collett GP (2005) Chemopreventive properties of curcumin Future Oncol 1: 405-414.

21. Singh S, Khar A (2006) Biological effects of curcumin and its role in cancer chemoprevention and therapy. Anticancer Agents Med Chem 6: 259-270.

22. Maheshwari RK, Singh AK, Gaddipati J, Srimal RC (2006) Multiple biological activities of curcumin: a short review. Life Sci 78: 2081-2087.

23. Anand P, Sundaram C, Jhurani S, Kunnumakkara AB, Aggarwal BB (2008) Curcumin and cancer: an "old-age" disease with an "age-old" solution. Cancer Lett 267: 133-164.

24. Kunnumakkara AB, Anand P, Aggarwal BB (2008) Curcumin inhibits proliferation, invasion, angiogenesis and metastasis of different cancers through interaction with multiple cell signaling proteins. Cancer Lett 269: 199-225.

25. Ikezaki S, Nishikawa A, Furukawa F, Kudo K, Nakamura H, et al. (2001) Chemopreventive effects of curcumin on glandular stomach carcinogenesis induced by $\mathrm{N}$-methyl-N'-nitro-N-nitrosoguanidine and sodium chloride in rats. Anticancer Res 21: 3407-3411.

26. Šmerák P, Polívková Z, Šestáková H, Štetina R, Bárta I, et al. (2006) Antimutagenic Effect of Curcumin and its Effect on the Immune response in Mice. Czech Journal of Food Sciences 24: 72-83.

27. Johnson JJ, Mukhtar H (2007) Curcumin for chemoprevention of colon cancer Cancer Lett 255: 170-181.

28. Thomasset SC, Berry DP, Garcea G, Marzylo T, Steward WP, et al. (2006) Dietarypolyphenolic phytochemicals - promising cancer chemopreventive agents in humans? A review of their clinical properties. Int JCancer 120: 451458.

29. Von Löw EC, Perabo FG, Siener R, Müller SC (2007) Review. Facts and fiction of phytotherapy for prostate cancer: a critical assessment of preclinical and clinical data. In Vivo 21: 189-204.

30. Thangapazham RL, Sharma A, Maheshwari RK (2006) Multiple molecular targets in cancer chemoprevention by curcumin. AAPS J 8: E443-449.
31. Singh RP, Agarwal R (2006) Mechanisms of action of novel agents for prostate cancer chemoprevention. Endocr Relat Cancer 13: 751-778.

32. Shishodia S, Singh T, Chaturvedi MM (2007) Modulation of transcription factors by curcumin. Adv Exp Med Biol 595: 127-148.

33. Meeran SM, Katiyar SK (2008) Cell cycle control as a basis for cancer chemoprevention through dietary agents. Front Biosci 13: 2191-2202.

34. Gautam SC, Gao X, Dulchavsky S (2007) Immunomodulation by curcumin. Adv Exp Med Biol 595: 321-341.

35. Šmerák P, Šestáková H, Polívková Z, Bárta I, Turek B, et al. (2002) Antimutagenic effect of ellagic acid and its effect on the immune response in mice. Czech Journal of Food Sciences 20: 181-191.

36. Ames BN (1971) The detection of chemical mutagens with enteric bacteria, In Hollaender, Chemical mutagens, Principle and methods for their detection. Plenum New York: 267-282.

37. Ames BN, McCann J, Yamasaki E (1975) Methods for detection of carcinogens and mutagens with Salmonella/mammalian-microsome mutagenicity test. MutatRes 31: 347-364.

38. Maron DM, Ames BN (1983) Revised methods for the Salmonella mutagenicity test. Mutat Res 113: 173-215.

39. erná M, Dobiáš L, Hájek V (1989) Amesova metoda, V. Metody biologického monitorování genotoxických úink faktor prostedí - Standartní metodika. Acta Hygienica Epidemiologica et Microbiologica 20: 33-56.

40. Schmid W (1975) The micronucleus test. Mutat Res 31: 9-15.

41. Wattenberg LW (1966) Chemoprophylaxis of carcinogenesis: a review. Cancer Res 26: 1520-1526.

42. Langová M, Polívková Z, Šmerák P, Bártová J, Bárta I (2005) Antimutagenic effect of resveratrol. Czech J Food Sci 23: 202-208.

43. Polívková Z, Langová M, Šmerák P, Bártová J, Bárta I (2006) Antimutagenic Effect of Genistein. Czech J Food Sci 24: 119-126.

44. Bárta I, Smerák P, Polívková Z, Sestáková H, Langová M, et al. (2006) Current trends and perspectives in nutrition and cancer prevention. Neoplasma 53: 19-25.

45. Smerák P, Polívková Z, Stetina R, Bártová J, Bárta I (2009) Antimutagenic effect of phenethyl isothiocyanate. Cent Eur J Public Health 17: 86-92.

46. Polívková Z, Šmerák P, Demová H, Houška M (2010) Antimutagenic effects of lycopene and tomato purée. J Med Food 13: 1443-1450.

47. Zoubková H (2014) Green tea against a mutagenicity. Výživa a potraviny 3 : 80-82.

48. Murakami A, Takahashi D, Koshimizu K, Ohigashi H (2003) Synergistic suppression of superoxide and nitric oxide generation from inflammatory cells by combined food factors. Mutat Res 523-524: 151-61.

49. de Kok TM, van Breda SG, Manson MM (2008) Mechanisms of combined action of different chemopreventive dietary compounds: a review. Eur J Nutr 47 Suppl 2: 51-59.

50. Hemalswarya S, Doble M (2006) Potential synergism of natural products in the treatment of cancer. Phytother Res 20: 239-249.

51. Verma SP, Salamone E, Goldin B (1997) Curcumin and genistein, plant natura product, show synergistic inhibitory effect on the growth of human breas cancer MCF-7 cells induced by estrogenic pesticides. Biochem Biophys Res Commun 233: 692-696.

52. Lev-Ari S, Zinger H, Kazanov D, Yona D, Ben-Yosef R, et al. (2005) Curcumin synergistically potentiates the growth inhibitory and pro-apoptotic effect of celecoxib in pancreatic adenocarcinoma cells. Biomed Pharmacother 59: 276280 .

53. Lev-Ari S, Strier L, Kazanov D, Madar-Shapiro L, Dvory-Sobol H, et al. (2005) Celecoxib and curcumin synergistically inhibit the growth of colorectal cancer cells. Clin Cancer Res 11: 6738-6744.

54. Mertens-Talcott SU, Percival SS (2005) Ellagic acid and quercetin interact synergistically with resveratrol in the induction of apoptosis and cause transient cell cycle arrest in human leukemia cells. Cancer Lett 218: 141-151.

55. Kowalczyk MC, Kowalczyk P, Tolstykh O, Hanausek M, Walaszek Z, et al (2010) Synergistic effects of combined phytochemicals and skin cancer prevention in SENCAR mice. Cancer Prev Res (Phila) 3: 170-178. 
Citation: Zoubková H, Šmerák P, Polívková Z (2015) Antimutagenic Effect of the Ellagic Acid and Curcumin Combinations. J Environ Anal Toxicol 5: 296. doi:10.4172/2161-0525.1000296

Page 8 of 8

56. Aftab N Vieira A (2010) Antioxidant activities of curcumin and combinations of this curcuminoid with other phytochemicals. Phytother Res 24: 500-502.

57. Malhotra A, Nair P, Dhawan DK (2011) Curcumin and resveratrol synergistically stimulate $\mathrm{p} 21$ and regulate cox-2 by maintaining adequate zinc levels during lung carcinogenesis. Eur J Cancer Prev 20: 411-416.

58. Masuelli L, Marzocchella L, Focaccetti C, Tresoldi I, Palumbo C, et al. (2012) Resveratrol and diallyl disulfide enhance curcumin-induced sarcoma cell apoptosis. Front Biosci (Landmark Ed) 17: 498-508.

59. Ahn D, Putt D, Kresty L, Stoner GD, Fromm D, et al. (1996) The effects of dietary ellagic acid on rat hepatic and esophageal mucosal cytochromes P450 and phase II enzymes. Carcinogenesis 17: 821-828.

60. Duvoix A, Blasius R, Delhalle S, Schnekenburger M, Morceau F, et al. (2005) Chemopreventive and therapeutic effects of curcumin. Cancer Lett 223: 181190.

61. Celik G, Semiz A, Karakurt S, Arslan S, Adali O, et al. (2013) A comparatdive study for the evaluation of two doses of ellagic acid on hepatic drug metabolizing and antioxidant enzymes in the rat. Biomed Res Int 2013: 358945
62. Oetari S, Sudibyo M, Commandeur JN, Samhoedi R, Vermeulen NP (1996) Effects of curcumin on cytochrome P450 and glutathione S-transferase activities in rat liver. Biochem Pharmacol 51: 39-45.

63. Piper JT, Singhal SS, Salameh MS, Torman RT, Awasthi YC, et al. (1998) Mechanisms of anticarcinogenic properties of curcumin. The effect of curcumin on glutathione linked detoxification enzymes in rat liver. Int J Biochem Cell Bio 30: $445-456$.

64. Lila MA, Raskin I (2005) Health-related interactions of phytochemicals. Journal of Food Science 70: 20-27.

65. Lee JH, Khor TO, Shu L, Su Z-Y, Fuentes F, et al. (2013) Dietary phytochemicals and cancer prevention: Nrf2 signaling, epigenetics, and cell death mechanisms in blocking cancer initiation and progression. PharmacolTher 137: 153-171.

66. Garg AK, Buchholz TA, Aggarwal BB (2005) Chemosensitization and radiosensitization of tumors by plant polyphenols. Antioxid Redox Signal 7: 1630-1647.

67. Limtrakul P (2007) Curcumin as chemosensitizer. Adv Exp Med Biol 595: 269300 